\title{
Paradigms of Development and Their Power Dynamics: A Review
}

\author{
Md. Saidul Islam \\ Department of Sociology \\ The College of William and Mary \\ PO Box 8795. Williamsburg \\ VA 23187. USA \\ Tel: 757-221-2594, 757-903-4641, Fax: (757) 221-1007Ｅ-mail: msislam@wm.edu
}

\section{Acknowledgement}

This research was supported by Japan's Shipbuilding Industries Limited's "Graduate Fellowship for Academic Distinction" program at York University. For thoughtful comments and suggestions, the author gratefully thanks Dr. Peter Vandergeest, Dr. Stuart Schoenfeld, and Dr. Hira Singh.

\begin{abstract}
Development and power are two most fundamental ingredients and processes of social life. While the pervasiveness of power in the discourse of development has largely been obscured and camouflaged by paradigms of modernization and neo-liberalism, dependency theory has actually discovered that power-relations. Recently, with the emergence of post-modern critique of development, power has become an important subject in the discourse of development. Nevertheless, a full theoretical understanding of the relations between power and development is still in its nascent stage. Though highly apparent in human societies, social power per se is a polylithic discourse with no unified definition and implication, which led different proponents of development paradigms to understand power differently. This paper is a comprehensive survey of how power is understood in different paradigms/schools of development.
\end{abstract}

Keywords: Development, Power, Modernization, Dependency, Post-Modern, NGOs, Community based resource management

\section{Introduction}

Despite mounting criticisms (Note 1), development is still a master concept and one of the most indispensable ingredients of human society. The concept of development was popularized through expansion of colonization, and underwent various transformations as the socio-political structure of the world changed over time. During the era of colonization, development was understood as having colonies, organizing the European societies and its labour and market forces by disorganizing the non-European colonies. (Hoogvelt 2001; Cowen and Shenton 1996; Scott 1998; McMicahel 2000). After the end of World War II, a new phase of development emerged, as the newly independent countries, for the sake of political legitimation, adopted the western notion/model of development. They had to depend on the technologies of the former colonial masters. The adoption of European model across the formerly colonial world in the post World War II era was the underpinnings of what McMicahel (2000) calls the "development project". The USA was a powerful reality at that time. Asian and African decolonization started at the time when USA was at the height if its power and prosperity, and eager to reconstruct the postwar world to expand markets and the flow of raw materials. Reconstructing a war-torn world was an international project, inspired by a vision of development as a national enterprise to be repeated across the world of newly independent states (McMichael 2000; Hoogvelt 2001; Griffin 1989).

From the part of the West, especially from the USA, this development was viewed as a concept based on "democratic fair dealing" (McMichael 2000, p. 23). For the Americans and their allies, this was a liberal vision projected globally - a vision of universal political opportunity to pursue national economic growth. Therefore, the discourse of development assumed additional meanings - understood more as a natural process, with universal application, than the colonial initiative. That is, development could be administered by non-Europeans. This new development paradigm, however, ignored and obscured the contribution of former colonies to European development. In short, the development projects, as summarized by McMichael (2000, P. 75), were understood as: (a) an organizing concept to provide universal meaning (e.g., development as emulating Western living standards, rationality, and scientific progress); (b) a national framework for economic growth; (c) an international framework of aid (military and economic) binding the 
developing world to the developed world; (d) a growth strategy favoring industrialization; (e) an agrarian reform strategy encouraging agro-industrialization; (f) central state initiatives to stimulate and manage investment and mobilize multi-class political coalitions into a development alliance supporting industrial growth.

Whatever is the outcome, western intellectuals formulated and accepted this western notion of development as the only standard for the globe. If we evaluate the development project, we can discern at least three significant points: first, the projects has been modified in various ways since 1950s, as the world has changed; secondly, it is increasingly questioned as some of its expectations have failed to materialize, which gave rise to the emergence of neo-Marxist dependency school; and third, the founding assumptions and practices of development project represented historical choice rather than an inevitable unfolding of human destiny. The development project was an organized strategy to overcome the legacies of colonialism. Development became an organizing principle to shape world politics and to determine relations, mostly power relation, between the Third World (Note 2) countries and industrialized developed world.

Over the last few decades, the field development studies embraced a diverse range of intellectual pursuits, albeit no sense of common purpose and direction. First, the field has fragmented into area studies, in which the success of East Asian "developmental" states offered a promising focus for theoretical renewal, albeit rather more to the field of comparative political economy than to the subject of development studies itself. Second, there were meta-theoretical critiques of those theoretical constructs that had long constituted the toolbox of development theory. Dependency, exploitation, unequal exchange, mode of production, modernization, rationalization, progress - all these came under the deconstructing axe of post-modernists, post-Marxists, and post-structuralists alike. Third, some development literature merged with the literature of the international political economy. Fourth, the inclusion of gender and environment is very evident in the development literature today (Hoogvelt 2001). And finally, pervasive notion of power inherent in the discourse of development has been uncovered by the post-modern theorists. This paper is a comprehensive survey of the literature and understanding of how power is understood in different theories/schools of development.

\section{Development and Power}

\subsection{Liberal/Modernization Framework of Development}

Modernization is a theory of social and economic development that follows functionalist or consensus assumptions that societies need to have harmony among their components. This assumption leads to the belief that modern economies (capitalist) demand special characteristics in their culture and the structure of social relationships (Cowen and Shenton 1996; Hoogvelt 2001). For example, family systems are assumed to change toward a narrow conjugal form, and away from extended structure, in order to accommodate the individualism and occupational flexibility that is demanded by a modern complex economy undergoing continual transformation.

Modernization theory evolved from two ideas about social change developed in the nineteenth century: the conception of traditional vs. modern societies (gemeinschaft vs. gesellschaft), and positivism that viewed development as societal evolution in progressive stages of growth (Rostow 1960; Hoogvelt 2001). The unique characteristics of modern capitalist society, as viewed by Max Weber, is its "formal rationality", the best means (rational calculation) to achieve given ends (profit) as opposed to "substantive rationality" of traditional society; and "organic solidarity", of modern society, which is based on the recognition of difference, contractual laws, and individual rights rather than shared identity, as opposed to "mechanical solidarity" based on homogeneity and collective consciousness of traditional society as viewed by Emile Durkheim (Collins and Makowsky 1998).

In Modernization theory, problems that held back the industrialization of poor countries were related to the "irrational" way in which resources were allocated in a traditional society. Traditional societies became modern by rationalizing resource allocation, and by the elimination of cultural, institutional and organizational roadblocks that did not allow countries to develop. Developing countries with traditional societies could evolve by starting in a stage with an undeveloped and traditional society, and through an evolutionary linear process change its society by rationalizing it, becoming a country in a stage with a modern and developed society. The theory identified different stages, variables and process through which a society develops. Positivist evolution implied that all societies would pass through the same set of stages that the western society had passed: from a traditional to a modern society. The modernization stages were: 1) the traditional society, 2) preconditions for take-off, 3) take-off, 4) the drive to maturity, and 5) the age of high mass consumption. These five stages of modernization were known as Rostow's stage theory (Rostow 1960, Hunt 1989). From a Modernization perspective, the degree of industrialization, urbanization, and cultural values are the main indicators of changes in development in a country. Therefore, the level of use and access to information technologies within a society is captured by these indicators, but use is basically determined by the degree of rationalization of a society and cultural values towards science and technology.

According to Modernization theory, changes in openness to ideas and a more global sense of belonging would occur when changes in development occurred. Modernization also implies that a society's culture value system and 
institutional configuration determines its potential for development. It places the ideas and differing value systems, and not the material conditions, at the center of the explanation of the disparities in development (Hoogvelt 2001; Cowen and Shenton 1996).

There are various paradigm shifts or transformation within modernization/ capitalist framework. During the twentieth century, the two-sector (traditional vs industrial) model vividly identifies the capitalist or industrial sector as the engine of growth and development for the developing world. Capitalism in the mid-20th century was defined by an era known as Fordism, marked by intense relationships between governments, unions, international capital; this type of economics is still under state control. WWII gave a boost to industries that required mass production (chemicals, steel, etc.), and Fordism's heyday was between 1945 and 1973. Since the 1970s, Fordism has given way to Post-Fordism characterized by: 1) Business switch from industry to service; 2) New patterns of industrial distribution; 3) Intensifying globalization: a) global capital floats all over the world, states often lose control (e.g., Black Wednesday). b) fewer and fewer people control more and more production. 4) Weakened power of trade unions, less secure jobs, increase in low-paid jobs, etc.; and 5) Contemporary capital is hypermobile and hyperflexible (Hoogvelt 2001, Rist 2002).

Behind the backdrop of the earlier theoretical development, a paradigm shift has occurred during the mid and late $20^{\text {th }}$ century known as Neo-liberalism. Neo-liberalism has been designed, pushed and implemented by some of the biggest and most powerful institutions in the world like the International Monetary Fund (IMF) and the World Bank (WB). The policies of Neo-liberalism include privatization, marketization, and globalization (Lefeber 2003). The story of neo-liberal economics and globalization also includes the Kuznet's (1955) "Inverted U" hypothesis. The Kuznet's theory says that when a country begins developing economically, its income inequality worsens. But after a few decades when the rich begin investing more in the economy and wealth begins to "trickle down", income equalizes and people are wealthier than they would have otherwise been. The multilateral financial institutions, which have adopted this theory, namely the IMF, enforce structural adjustment programs on heavily indebted third world countries. These programs aim to get the state out of the economy through a number of measures known as "shock therapy" and at the same time create conducive environment for the forces of globalization to take off (Hoogvelt 2001; Cowen and Shenton 1996).

Modernization framework of development was considered by some as an oversimplified and generalized theory with strong racial stereotype and cultural bias. It ignored specific historical experiences and phases of prosperity in societies that had not changed their "traditional culture". Modernization theory was attacked as ahistorical, (ignoring phases of prosperity from a broader historical review), and ethnocentric (assuming that only one culture and one path were ways to development) (Hoodvelt 2001; Rist 2002; Pett and Hartwick 1999). World Systems Theory contested Modernization theory by suggesting that development differences were largely explained by taking into account the initial conditions and the relations of dependency in trade relations among countries in a whole system, i.e. the "world system". According to World Systems Theory, the global digital divide is really a reflection of the divides already present better explained by the degrees of peripherilization (a country's position in the core, semi-periphery or periphery). Countries in the wealthy core were bound to forge ahead in the use of new information technologies leaving behind countries in the deprived and dependent periphery. In consequence, the digital divide is a predicted consequence of the structure of the world system, in which less developed countries become more peripherilized when they are penetrated by interests located in the core: information and communication technologies are no exception to the core-periphery relation (Hoogvelt 2001; Rist 2002). Most importantly, modernization theory obscures the production and relations of power between developed and developing nations that pose a major hindrance to development of "traditional societies" as many claim. Paradoxically, others claim that the same sort of power relation is needed for the development of the traditional societies. Power and development are both related dialectically and reciprocally.

\subsection{Modernization Paradigm and Power}

How power affects, and is affected by, development is very complex yet interesting. Surrounding power, one of the first in-depth critiques of capitalism's inequities was by Karl Marx. Marxism was a Hegelian-inspired philosophy that concentrated on political economy, calling attention to unequal power relations between classes in capitalist society. It was an economic-deterministic perspective of the world. Marx's base-superstructure theory (economic base provided for cultural superstructure) was later elaborated by theorists such as Antonio Gramsci (Note 3), who elaborated post-Marxist theories of hegemony. Gramsci elaborated Marx's base-superstructure theory (economic base provided for cultural superstructure) with his theory of hegemony, i.e., that in modern society the subjugated classes willingly accept their exploitation by their rulers in society (Fontana 1993).

"Hegemony"- the willing acceptance of one social group's dominance and control by another and the dominating group's main vehicle of control — can be seen in terms of the more complex view of social structure, elaborated for the analysis of popular culture, developed in recent years within the Gramscian tradition and articulated by theorists such as Stuart Hall. However, an understanding of the more fundamental use of the term is also important. While it is difficult to find an adequate definition for hegemony, Todd Gitlin (2003, p. 253) gives a sense of how the concept works: 
$[\mathrm{H}]$ egemony is a ruling class's (or alliance's) domination of subordinate classes and groups through the elaboration and penetration of ideology (ideas and assumptions) into their common sense and everyday practice; it is the systematic (but not necessarily or even usually deliberate) engineering of mass consent to the established order. No hard and fast line can be drawn between the mechanisms of hegemony and the mechanisms of coercion...In any given society, hegemony and coercion are interwoven.

In the 1920s, the Frankfurt School developed as a German Marxist critique of capitalism in ideological terms (as opposed to economic terms). The Frankfurt School's position broadly was that people are easily fooled by capitalism and the culture industry. Reality was that created by bourgeois society in capitalism - culture is processed through culture industry. This is quite different from enlightenment ideas of affirmative culture, harmony, authenticity, encompassing the best of the people when authentically free. The school looked at ideology as characterizing distortions of reality -its purpose is to camouflage and legitimate unequal power relations. The work of the Frankfurt School laid the basis for many more recent critiques of capitalist-inspired mass culture (Fontana 1993).

Proponents of modernization paradigm, however, have a modest understanding of power, though no consensus among themselves. Unlike Marxian perspective, which views power as limiting, proponents of modernization view that power is something contributing to the entire social fabrics. They view it is the mass population that has the ultimate power: power to consume, power to boycott products, power to elect their leaders to govern themselves. Development is thus a democratic fair dealing (McMichael 2000) with power centered in the opinion of the masses. Some proponents of modernization paradigm subscribe the elitist perspective of power, which rationalizes the fact that in order for survival and smooth functioning of a society, it must be run by an efficient few elites who are elected by the majority of its citizens. This model of understanding power and development pervades till late nineteen and early twentieth century.

Another, mostly recent, cohort of proponents think that power is something prevalent in every stages of development activities, not centered in the "bourgeoisie" as Marx claims. They subscribe a pluralist model of power in development discourse. The donors of development projects, the researchers, the activists, the local populations or indigenous communities, academic personnel- all possesses power of their own and can influence each other. Development is pursued through a complex web of power exertion with one influencing other. This model is generally presented in response to the post-modern critique of development discourse.

\subsection{Dependency Theory}

Although dependency theory, like modernization theory, emerged in the post-war period, based on Marxian understanding of power, it had intellectual roots stretching into the past. Classical theories of imperialism had also addressed relations of domination and subjection between nations. According to dependency school, underdevelopment is seen as the result of unequal power relationships between rich developed capitalist countries and poor developing ones. In the past colonialism embodied the inequality between the colonial powers and their colonies. As the colonies became independent the inequalities did not disappear. Powerful developed countries such as the U.S., Europe and Japan dominate dependent powerless least developed countries (LDCs) via the capitalist system that continues to perpetuate power and resources inequalities (Hoogvelt 2001).

Dominant most developed countries (MDCs) have such a technological and industrial advantage that they can ensure the global economic system works in their own self-interest. Organisations such as the World Bank, the IMF and the WTO have agendas that benefit the firms, and consumers of primarily the MDCs. Freeing up world trade, one of the main aims of the WTO, benefits the wealthy nations that are most involved in world trade. Creating a level playing field for all countries assumes that all countries have the necessary equipment to be able to play. For the world's poor this is often not the case (Khor 2001, Hoogvelt 2001).

Unlike modernization theory which blames the culture of the underdeveloped, in dependency model the responsibility for lack of development within LDCs rests with the MDCs. Advocates of the dependency theory argue that only substantial reform of the world capitalist system and a redistribution of assets will "free" LDCs from poverty cycles and enable development to occur. Measures that the MDCs could take would include the elimination of world debt and the introduction of global taxes such as the Tobin Tax. This tax on foreign exchange transactions, named after its proponent, the American Economist, James Tobin, would generate large revenues that could be used to pay off debt or fund development projects (Khor 2001; Hoogvelt 2001).

There are some problems in this model as well and hence it is very difficult to implement. First, power is not easily redistributed, as countries that possess it are unlikely to surrender it. Secondly, it may be that it is not the governments of the MDCs that hold the power but large multinational enterprises that are reluctant to see the world's resources being reallocated in favour of the LDCs. Thirdly, the redistribution of assets globally will result in slower rates of growth in the MDCs and this might be politically unpopular. 


\subsection{Post-Modern Critique: Development as a Regime of Knowledge/Power}

The postmodern critique of development by writers like Ferguson (1990), and Escobar (1995) see development discourse as nothing more than an apparatus of surveillance and control. Even though they do not identify themselves as purely Marxist, or Foucaultian, they are highly influenced by intellectual traditions of Marx and Foucault. In order to maintain a focus on the notion of power and domination, as well as on the most pervasive effects of development, they see development in terms of discourse, as discourse analysis creates the possibility of, as Escobar (1995) quotes from Foucault (1986), 'stand[ing] detached from [the development discourse], bracketing its familiarity, in order to analyze the theoretical and practical context with which it has been associated' (p. 6). Escobar sees development from discourse analysis:

To see development as a historically produced discourse entails an examination of why so many countries started to see themselves as underdeveloped in the early post-World War II period, how "to develop" became a fundamental problem for them, and how, finally, they embarked upon the task of "un-underdeveloping" themselves by subjecting their societies to increasingly systematic, detailed, and comprehensive interventions. As western experts and politicians started to see certain conditions in Asia, Africa, and Latin America as a problem - mostly what was perceived as poverty and backwardness - a new domain of thought and experience, namely development came into being, resulting a new strategy of dealing with the alleged problems. Initiated in the United States and Western Europe, this strategy became in a few years a powerful force in the Third World (1995, p. 6).

Escobar (1995) nicely delineates how 'poverty' was discovered and 'problematized' and the 'Third World' was constructed in the discourse of development, and how two-third of the world population was put under the regime of control by discursive practices. 'The poor increasingly appeared as a social problem requiring a new ways of intervention in society' (p. 22), and 'the treatment of poverty allowed society to conquer new domains' (p. 23). The management of poverty called for interventions in education, health, hygiene, morality, and employment, and the instilment of good habits of association, savings, child rearing and so on. The result was a panoply of interventions that accounted for the domain of knowledge and intervention. Not only poverty, but also health, education, hygiene, employment, and poor quality of life in towns and cities were constructed as social problems, requiring extensive knowledge about the population and appropriate modes of social planning (Escobar 1992). 'The most significant aspect of this phenomenon was the setting into place of apparatuses of knowledge and power that took upon themselves to optimize life by producing it under modern, "scientific" conditions' (Escobar 1995, p. 23).

The result of these construction and practices was very pervasive. The poor countries started defining themselves in relation to the standard of wealth of the more economically advantaged nations. This economic conception of poverty (comparative statistical operation) found an ideal yardstick in the annual per capita income. Thus 'two-third of the world's people were transformed into poor subjects in 1948 when the World Bank defined as poor those countries with an annual per capita income below $\$ 100$. And if the problem was one of the inefficient income, the solution was clearly economic growth. Thus poverty became an organizing concept and object of new problematization' (Escobar 1995, pp. 23-24).

If we delve deeply into this construction, we will find an inherent power relation. The Third World is constructed by distancing it away from the civilized and developed West. This distance, which is not a simple marker of cultural diversity, is branded with inferiority and negativity (backward, underdeveloped, poor, lacking, traditional...). When these kinds of negative images are constructed on a group of people, they automatically become preamble to certain treatments and interventions, and thus, the former justifies the latter. Due to the construction of the Third World, the power relation between the agency who constructs, and constructed subjects becomes "father-child" or "doctor-patient" (Escobar 1995, p. 159).

With the construction of the Third World, as Escobar (1995) sees, the rich countries of the West 'created an extremely efficient apparatus for producing knowledge about, and exercise of power over, the Third World' (p. 9). New form of power and control, more subtle and refined, were put in operation. The poor people's ability to define and take care of their lives was eroded in a deeper manner than perhaps before. The poor became the target of more sophisticated practices of variety of programmes that seemed inescapable' (p. 39). Various programmes, institutions, centres of power proliferated in the West to study these 'poor subjects' and their conditions. The Third World then witnessed 'a massive landing of experts, each in charge of investigating, measuring, and theorizing about this or that little aspect of the Third World societies' (p.45).

To understand development as a discourse, one must look not at the elements themselves, but at the system of relations established among them. 'It is a system that allows the systematic creation of objects, concepts, and strategies... the system of relations establishes discursive practices that sets the rule of the game: who can speak, from what point of view, with what authority, and according to what criteria of expertise. It sets the rules that must be followed for this or that problem, theory, or object to emerge and be named, analyzed, and eventually transformed into a policy plan' (pp. 
40-41). However, not all have the authority to do that. 'Some clear principles of authority were in operation. They concerned the role of experts, from whom certain criteria of knowledge and competence were asked; institutions, such as UN, which had the moral, professional, and legal authority to name subjects, and define strategies; and international lending organizations, which carried the symbols of capital and power' (p. 41). The principle of authority also concerned the governments of the poor countries, which commanded the legal political authority over the lives of their subjects, and the position of leadership of the rich countries, who had the power, knowledge and experience to decide on what was to be done. Therefore, the exercise of power/power-relation is evident between and within developed nations, and poor countries. In Escobar's (1995) word:

Economists, demographers, educators, and experts in agriculture, public health, and nutrition elaborated their theories, made their assessments and observations, and designed their programs from these institutional sites. Problems were continually identified, and client categories brought into existence. Development proceeded by creating "abnormalities" (such as the "illiterate", the "underdeveloped", the "malnourished", "small farmers", or "landless peasants"), which it would later treat and reform. Approaches that could have positive effects in terms of easing material constraints became, linked to this type of rationality, instruments of power and control (pp. 41-42).

Patriarchy and ethnocentrism, the obvious manifestation of power and control, are inherent in the discourse of development. The indigenous people have to be modernized in line with the appropriate 'values' (western-white). It gives them an understanding of their own culture as 'backward', or 'evil' or 'inimical to development' (McMichael 2000). A sense of inferiority complex permeates over their body and soul. It has profound effects on their lives and way of thinking, and becomes a sophisticated way of exercising power and control. As Lohmann (1999) says, 'racism is a process of social control, not a set of beliefs and feelings' (p. 70).

The subordinate power relation is normalized in such a way that it goes uncontested and accepted as usual. The subject people often accept that as their fate. The history has witnessed the fact that development planners (most economists$75 \%$ in World Bank), and Engineers, by their economistic mind-set, create models, calculations, and formulate plans, which often has no relation to the actual population, the subjects, and to how they (the subjects) see their own problems and solutions. Due to this problem, most development projects become unsuccessful and create tensions. Interestingly, when any project fails to materialize its target, the blame goes to the victims and their culture, not the planners. It is the organization, which plans, creates categories, and finally also constructs the blames. For example, for ecological disasters caused by development programmes, the poor are blamed and "admonished for their "irrationality" and their lack of environmental consciousness' (Escobar 1995, p. 195). Institutional Ethnography is, as Escobar suggests, helpful to study the organization, especially its ideology.

From the discussion, it appears that what development reveals is intended to hide or occlude something. It is constantly expanding its power by constructing new domains. The conspicuous process is problematization: creating knowledge in a very efficient way, institutionalization: bureaucratization and managerialism, and finally normalization of power. This is what Michel Foucault $(1979,1986)$ discovers and explicates the relation and exercise of power in the modern society. One of the apparent implications of this extension of power is that it 'privilege[s] certain actors, and marginalize[s] others' (Brosius 1999, p. 38).

Apart from the above critiques, since 1980s there emerged another group, the group who might be called "ultra-modernist". It consists of economic theorists who insist that the laws of economics have been proven valid, that the invisible hands of the market allocate resources optimally. Therefore, there is only economics, not development economics. When governments and outside agencies try to make the market work better, they introduce doctrines, which make it work worse. The free market does not guarantee equality of income, they say, but it produces as optimal an allocation of resources as is possible (Cooper and Packard 1997).

\section{Development Projects and their Power Negotiation}

Over past few decades, development faced mounting criticism because of its failure to bridge the gap between developed and developing nations. One of the key criticisms is surrounding unequal power relation. The harshest criticism came from under-development/dependency theorists. They not only indicated the problems and flaws inherent in the capitalist paradigm, but also advocated an alternative vision of development. But after the demise of USSR and its eventual entry to global capitalist club, and secondly China's gradual penetration to, and acceptance of, free-market economy, their alternative vision is losing market currency. The post-modern critics of development, despite their thoughtful explication to equate development with power exertion, failed to suggest any development agenda alternative to capitalist paradigm. As different criticisms appear, the capitalist paradigm is now undergoing different transformations and trying to adopt and show a pluralist model of power relations involving and empowering the locals. Here are some key models and current debates surrounding them. 


\section{1 “Empowering” Civil Society and Ensuring "Good Governance”: Role of NGOs}

NGOs are more popular than ever in official circles these days. However, while ten years ago, their popularity lay largely in their supposed efficiency in meeting the basic needs of the people at the grassroots-i.e., in 'tackling poverty',--today they are being trumpeted, according to UNDP Human Development Report (1993), as representative per excellence of civil societies in the so-called Third World. In the post-Cold war era, international institutions and donor agencies are turning their attention increasingly to concerns about democratization and popular participation. As UNDP report dramatically puts it, “Greater people's participation is no longer a vague ideology based on the wishful thinking of new idealists. It has become an imperative - a condition of survival” (Keck and Sikkink 1998). But again, NGOs involvement in development projects and influencing national politics raises numerous questions and skepticism.

Wood (1997) is quite skeptical regarding the proliferation of NGOs in the developing countries. According to him, for NGOs to operate, for markets to penetrate and to hold authority, for private organizations to take hold of the societies' power, the first thing that should be done is to diminish the power and authority of the state by curtailing its role in providing services to its citizen, and by reducing its control on resources. This is a neo-liberal agenda, and to do that it advocated the rhetoric of "good governance" which is paradoxical in meaning and operation. Wood calls this scenario "franchise state" (state franchising its responsibility to NGOs).

In the West "Good governance" is explained as "democratic process with strong accountability between state and people, removing the prospects of dictatorial oppressive governments and underpinning, therefore, the protection of fundamental human rights" (Wood 1997, p. 97). Wood calls it "hypocrisy" embodied in the western preoccupation of the theme "good governance". He argues that the "good governance" represents a revival of ethnocentric, modernizing ideology, attempting to make the myths of one society reality in another. Giving the example of UK, he says, "Good governance is more possible elsewhere than in those countries which purport to be the keepers of the discourse" (p. 80).

When one talks about 'good governance', there arise many questions and problems, especially the problem of accountability. First of all, "good" is not universal, rather relative, and contingent upon cultural expectations and distributional outcomes. The paradoxes in the notion of 'good governance" include,

(a) The thrust of policy is to undermine the monopoly of the state in service provision and allocation of resources, thereby creating more opportunity for exit choices and thus reducing the necessity for government to be good.

(b) The preoccupations with privatizations and markets on the one hand, and good governance on the other, do not easily sit side by side.

(c) Adherence to neo-liberal views about the efficacy and the responsiveness of the market as an allocator of public goods crucially slides over the issue of responsibility. However, markets tend to ignore responsibility, and have been proven to be failure in distributing resources. Markets rather serve the capitalists for accumulation and legitimation (Panitch 1977).

(d) "Good governance" is geared to improve "participation". It is very contradictory, as most NGOs are operated in an authoritative manner.

(e) "Good governance" undermines and limits the capacity and power of the state, but state remains responsible for defining, guaranteeing, and regulating entitlements on the one hand and delivery on the other. NGOs which are operating to improve 'good governance' are basically working to "break the state monopolies in both service and goods delivery and to remove regulations and licensing to allow market to breath" (Wood 1997, p. 86).

Wood further (1997) argues that the "Franchise Model" cannot be alternative to state and market, because markets have been proven to be inefficient allocator. Other skeptics argue that policies of IMF and World Bank in the developing countries virtually created more tensions and problems. East Asia, Russia, and Latin America are some examples (Lefeber 2003; Grinpun 2003; Stiglitz 2000; Weisbrot et al 2000), and they think that NGOs have close link with donors and other capitalist institutions, and hence they are mostly operated by the outsiders. It is dis-empowering for the locals as it erases their ability in a deep manner to define themselves and to take care of their own lives. Experience from the Orangi Pilot Project (OPP) (Hameed 1997), and Agro-forestry Outreach Project (AOP) (Murray 1997) shows, top-down approach is mostly ineffective.

Despite criticisms and skepticism, there are empirical proofs that NGOs play a vital role in empowering the locals, creating vigorous civil societies, ensuring participation of the local community in development activities and in making development more meaningful and accepted for them (Keck and Sikkink 1998).

\subsection{Community Based Natural Resource Management (CBNRM)}

In the midst of the exploitation of the natural resource as well as the local people/ forest or upland dwellers that results in severe environmental and social damage on the one hand, and direct control, and sometimes aggressive deployment of 'development projects' by the development agencies, community based natural resource management (CBNRM) 
paradigm has been proposed by many. It offers to (a) promote democracy and participation among the local people, including women, who are historically excluded, (b) create mechanism for their empowerment, (c) claim the natural resources that is extracted mainly by the state elite, (d) reorganize the local communities in legal entities/frameworks for the management of resources, (e) create networks from local to the international level, (f) make the development projects more fruitful by ensuring the participation of the local people, and thereby make it meaningful and accepted to them (Brosius et al 1998; Lynch and Talbot 1995; Li 2002).

Recognizing the fact that CBNRM offers an excellent paradigm to create voice for the historically excluded and oppressed local communities in the development projects, there arise lot of questions, concerns, paradoxes and some dangers. The key debates surrounding this model are as follows:

First, Owen Lynch (1995) adumbrates a concern that the impoverished rural communities in the developing world are denied the fundamental rights to substantive participation in decisions that impact on their well-being and livelihoods, and through CBNRM, their important participation can be ensured. The question arises: does participation really ensure democracy and lay any impact on decision-making? There is a need to look at how far their participation really affects decision-making. The danger is that the state and the development agencies can use participation for legitimacy. To me, the notion of participation is so complex that the community chiefs can be privileged, while the other vast number of people remains impoverished. Brosius et al (1998, p. 164) raised important questions, "How are powerful institutions, including multilateral financial organizations, bilateral aid agencies, national and transnational conservation organizations, and private sector actors appropriating community based natural resource management projects and policies to advance their own diverse, sometimes intersecting, interests? What are the political, cultural, environmental, and economic consequences of these appropriations and manipulations?" By engaging the local communities in the development activities, the development projects get unquestioned acceptance, and if the projects fail, blame goes to the local people as if they are not ready for the development. The question then arises, is CBNRM a legitimate guise or an 'ideological device', in Marxist term, to conquer the local terrain?

Secondly, the success of disseminating the paradigm of CBNRM has raised new challenges, as "the concepts of community, territory, conservation, and indigenous are worked into politically varied plans and programs in disparate sites" (Brosius et al 1998, p. 157). 'Indigenous' or 'native' is one of basic elements in the program of CBNRM, which is often used for resource claim. For example, Lynch (1995) made a distinction between Hispanicized and un-Hispanicized ethnic groups in Philippines. However, the notion of 'indigenous' is subject to contestation, as human history entails the fact that people are always in mobile often by better future and displacement by human and natural forces. Old and new migrants often interspersed among them, and cross-marriage, hybridity etc. are common phenomena in almost every community (Li 2002).

Tania Li's (2000) argument is that a group's self identification as tribal or indigenous is not natural or inevitable, but neither is it simply invented, adopted, or imposed. It is, rather, "a positioning, which draws upon historically sedimented practices, landscapes, and repertoires of meaning, and emerges through particular patterns of engagement and struggle" (Li 2000, p. 151). She elaborates that the conjectures at which some people come to identify themselves as indigenous, realigning the ways they connect to the nation, the government, and their own, unique tribal place, are the contingent products of agency and the cultural and political work of articulation. The concepts of articulation and positioning, which she draws from Start Hall $(1991,1996)$, are central to her analysis. Moreover, in the era of borderless world and transnational citizenry, the notion of 'indigenous' is gradually loosing its market value. Incorporation, integration into a new society is a very common picture of the modern society. Market citizenship is a new concept that contests the notion of 'indigenous' (Strange 1996).

On the other hand, the notion of 'indigenous' can be used for exclusionary purposes. Malaysia is a good example where the so-called "bumi-putra" (indigenous) gets extra-privilege, while the discursively constructed non-bumi-putra are historically excluded in many respects. Claiming or constructing 'indigenous identity' may lead to more complexity and conflict. Both Palestinians and Israelis are claiming to be indigenous that resulted in the circles of violence for long decades.

Another danger lies when the project of CBNRM uses ethnicity for land or resource claims, as again the 'ethnicity' is a very fragile term on the one hand, and construction of an ethnicity (for land/resource claims) may lead to an essentialized identity, on the other.

Third, one of the assumptions of CBNRM is that indigenous peoples' life is based on the forest resources (Lynch 1995). This kind of assumption is highly contested. "The characterization of indigenous people as forest resource dependent is more problematic" ( $\mathrm{Li}$ 2002, p. 267). The question arises: does it suggest that the forest dwellers should remain traditional and forest-dependent? In the era of advanced technology, science, and high communication, as well as decent and healthy style of life, can we imagine a life in the forest? The CBNRM talks about the management of forests by the forest-dwellers, but in reality the "tribal people are not being asked if or how they want to manage their forests" (Brown 
1994, p. 59). Li (2002) explicates that many tribal people in Indonesia and elsewhere denounced their tribal identity, as they do not want to pursue their future on the forests/hills.

Fourth, in projects of CBNRM, we see that community, territory, indigenous, traditional etc. are defined and constructed by the outsiders. It entails a regime of control and authority/power over them. The local people are turned into an 'object of knowledge' and lose their ability to define themselves in their own terms and to take care of their own affairs. The agencies decide who to speak, from what point of view. In Escobarian (1995) way, behind the construction and reconstruction of the local community in discourses and practices in the name of creating voice for them or to ensure their participation in the development projects, lies the lucrative interest of the powerful development agencies.

Escobar (1995) explicates how development expands by creating different domains of thought and discourses. The process includes problematization (creating knowledge in a very efficient way), institutionalization (bureaucratization and managerialism), and finally normalization of power, as we have elaborated before. One can argue that by deploying the regime of CBNRM, the local communities, who were outside the direct domination of development agencies, are now under the direct control and power.

Fifth, does CBNRM further lead to 'institutionalization' and 'managerialism' where the local communities become the objects of policies? Schroeder (1995) raises the concern that the language of community and conservation has, upon occasion, served to help shift resources away from local strategies for livelihood and empowerment towards resource management that served powerful institutional interest, whether corporate, scientific, military-administrative, or northern consumer-oriented. There is a need to explore how CBNRM, if goes towards institutionalization and managerialism, 'privilege a fortunate few and preclude other', if we quote Brosius (1999); how it affects the state government, and fate of the local communities; and how, if any, multilateral institutions and bilateral lending agencies have influenced national governments to enforce CBNRM by decree.

Sixth, the paradigm of CBNRM is based on a common assumption that state is an oppressive regime to the local community, and in order to create voice for the local communities, the state power needs to be subverted (Lynch 1995; Li 2002). Hence, we find various writings to construct state as an 'alien' to the local community. However, states may not always be aliens to local communities. Many think that undermining the state is necessary to create a vacuum for the market to penetrate and to take over the activities previously done by the state.

We are yet to be convinced that we have to oppose the state in order to create voice for the oppressed communities. However, one can argue that state is the still a legitimate organization/ institution to organize the people, to work for their well-being. Viewing state always as oppressive regime is a kind of simplification. We do not afford to ignore that in many developing countries, many local communities are oppressed, and many of them have already been displaced by the state. For instance, hundreds of Penan people in Sarawak, Malaysia (Brosius 1999), the forest-dwellers in Thailand (Lohmann 1999; Vandergeest and Peluso 1995, Islam 2003), and so-called Hispanicized people in Philippines (Lynch 1885) and others are in acute manipulation by the state. However, McMichael (2000) shows that most of the displacement and oppression is because of the aggressive deployment of development projects, and it is not the state that needs to be blamed alone, the powerful development agencies that deployed the development projects should be blamed. For instance, the agony of the highlanders in Thailand is mainly due to development agencies' proposal to "reduce the population of people in mountainous areas and bring them to normal life" (Lohmann 1999, p. 70). Rather than viewing state as a separate entity and hence subverting the power of state, we can think of a democratic state with equal and meaningful participation from all communities. Both state and community can be mutually constitutive. Here how nicely Li (2002) explicates:

A core concern of $\mathrm{CBNRM}$ has been to strengthen the capacity of the communities to protect their natural resource base from the more destructive and rapacious activities of ruling regimes, among others. The model envisages a shift in power from states to communities, conceived as separate entities. Instead, as I have argued, states and communities are mutually constitutive. CBNRM offers state system an opportunity to rearrange the ways in which the rule is accomplished, while also offering the communities an opportunity to realign their position within (but not outside) that system. Where citizens are indeed up against "vicious states", the potential of CBNRM to empower them is very limited. Older vocabularies about peasant struggles, class conflict, and democracy are better able to name the problem, and to indicate the forms of collective action through which it might be addressed (p. 281).

The above are some of critical points with regard to CBNRM. Scholars of CBNRM, the donor or development agencies, as well as the nation states need to keep all these in minds. We can envisage a fruitful collaboration and mutual power sharing between these three groups: communities, donor agencies, as well as the state, and that should be the goal of CBNRM, as well as development projects. We can conclude here by quoting Li (2002), "CBNRM serves as a vehicle for negotiating the responsibilities and rights of the citizenship. It is not, however, the only possible vehicle and its strengths and weaknesses need therefore be evaluated in relation to the alternatives" (p. 270). 


\section{Discussion and Conclusion}

"The development process has from its inception been self-critical, and subjects to critiques" (Cooper and Packard, 1997 , p. 2). From the analysis of development and power above, we can discern different accounts of history and analysis. In conventional analysis, development can be seen in terms of evolution of theories and ideas, or as the succession of more or less effective interventions (Leys 1996). For political economists, the same history reflects deferent ideological responses to allegedly deeper contradictions, dictated by capital accumulation and circulation, or also capital accumulation and legitimation (Panitch 1977). This history, however, can also be seen from the perspectives of the changes and transformations in the discursive regime, even if these changes are circumscribed by discursive practices tied to political economies, knowledge traditions, and institutions of ruling (Escobar 1995), and wherein lies the notion of power.

Hence, development is, in no way, a monolithic discourse. As it has different accounts of outcomes and gains, so has criticisms from different perspectives. It is accepted by a wide range of people, and simultaneously contested by many as well, while some have an ambivalent position. The prevalence of different accounts on the discourse of development certainly entails the fact that development is not all about power (knowledge-power-regime) as propounded by Escobar (1995) and his associates. From our analysis, we can safely say that development is rather both empowering and disempowering operated and functioned in a very complex interwoven ways of power relations. It empowers certain actors, spaces, and species, while disempowers others. "All development projects involve reorganizing the meaning and control of space" and have "the potential of causing displacement" (Vandergeest 2003, p. 47), not only for human beings but also for other species. With powerful vocabularies and various discursive practices, development creates categories, makes different spaces, disempowers those that appear inimical to, or compete with, development projects. Thus, in the process of reorganizing nature - by both empowering and disempowering-

Plants that are valued become "crops", the species that compete with them are stigmatized as "pests". Thus, trees that are valued become "timber", while species that compete with them become "trash" trees or "underbrush". The same logic applies to fauna. Highly valued animals become "game" or "livestock", while those animals that compete with or prey upon them become "predators" or "varmints" (Scott 1998, p. 13).

The arguments of dependency school as well as postmodernist critics are framed in such an impressive way that it often lead us to think that development is all about top-down power exertion and there are no other possibilities. It closes all the doors of viewing other perspectives. It is hence reductionistic, and stagnationistic. Unlike postmodernist critique of development (knowledge-power-regime), theorists of "underdevelopment/ dependency" propose a more radical alternative, quite akin to Marxist explanation of capitalism that we discussed before. The theory of 'underdevelopment', however, lost a considerable amount of market currency after the demise of USSR, and subsequently China's shift towards free-market economy, and capitalism remained the only viable alternative.

Rather than closing the door by deploying the discourse of 'dependency' or 'knowledge-power-regime' on development, we need to go further. The best way to view development is, to quote Cooper and Packard (1997), "neither to bury development, nor to praise it" (p. 4). They explain that over the past few decades, development encountered some passionate confrontations and criticisms, though in a limited scale, it, to some extent, if we view positively, provided a kind of 'check-and-balance' to development projects/endeavors. The debates are still on: the post modernists criticize developers for imposing undesired modernity, while developers reject the post-modernists' nihilism and statism of the more orthodox. Postmodernists attack on the developers that they, without interacting the target people, make calculation, create client groups, and prepare model for development, which eventually fail; while people engaged in development projects constantly insist that they are doing practical work interacting with the local people, and need models and more practical framework to make the progress more coherent and fruitful. In Cooper and Packard's words, "no side in these tussles has a monopoly of virtue, and all have something to gain by a more introspective, contingent view of the terrain upon which these battles have taken place" (1997, p. 4).

In the milieu of arguments and counter-arguments, critiques and counter-critiques, it is simplistic, we think, to be caught up on a single discourse, like the discourse of 'knowledge-power-regime' of 'dependency' or even 'modernization' hype. Sugata Bose (1997) elucidates India's historical experience of development in a comparative manner, and mentions that the development that India experienced over the century is neither simply a knowledge-making apparatus, nor enhancement of dependency. Development there created lot of possibilities, and has numerous achievements. Consequently, India, being powerful enough, is not only capable of managing its own economic affairs, but also provided the world with eminent experts in development economics. Gupta (1997), on the other hand, explains that development in India gave rise to different social movements among the poor who demanded for reform, sometimes, opposed projects, like building a dam, which are hazardous to the communities. From the discussion of Bose (1997) and Gupta (1997), it appears clear that development is more than the relation of power in an extreme hierarchical order, like "father-child", and "doctor-patient" (see Escobar 1995, p. 159) rather a complex web of power exertion both influencing and being influenced, popularly expressed as "pluralist" model of power exertion. 
The power relation and the regime of control as explicated by Escobar and Ferguson seem one-sided, solid, and vertically monolithic: the developers at the top and the Third World at the bottom. To them, development strengthens this power relation in a deeper manner. However, evidence shows that power is dynamic, and is exercised in different angles, and in variety of ways. Development does not always make the third world powerless, rather make them regain power. Women, beset by patriarchy, for example, gained a considerable amount of power due to development (Packard 1997). Cooper (1997) shows that the image of the African farmers survived is much evidence of innovation and the arrival of Africans in power.

Moreover, "within the world of development, power is distributed in a highly uneven manner" (Cooper and Packard 1997, p. 20). It is, therefore, important to see how institutions from World Bank to the local levels operate. Evidence shows that local level community networks (social movements) were able to evade, reject, or reform development projects (see, for example, Gupta 1997). Therefore, communities are not just the passive recipients of the development projects imposed by the developers; they have also choice and power.

According to Escobar (1995), the production and dissemination of development knowledge is always top down: from World Bank to the Third World/local, for example. They have the legal authority to name subjects, make client groups, and define strategies... (pp. 40-41). But this materialistic and simplistic explanation does not grasp all. It 'overlooks the specific networks of communication through which ideas circulate internationally. The power of an institution like World Bank is based as well on its position within overlapping global networks of research, communication, and training. The bank recruited internationally from developing and developed countries... and projects review documents... are disseminated globally' (Cooper and Packard 1997, p. 21).

The production and dissemination of development ideas is not always unilinear as Escobar sees. There are instances in which the local people provide knowledge to the World Bank. Gupta (1997) argues the development knowledge prevalent in India was not entirely produced and disseminated by the World Bank. On the one hand, India refined, and restructured the development knowledge provided by the World Bank, and produced some unique knowledge on development by the local expert, on the other hand, and contributed to the world arena. Therefore, the production and dissemination of development knowledge is not unilinear, rather reciprocal, contextual and subjects to revision. Furthermore, as Cooper and Packard (1997) explain, the successful transmission of ideas emanating from the powerful development organizations was also fostered by global political shifts. The end of Cold War narrowed development options by discrediting socialist alternatives. It is perhaps historically significant that the earlier post-war push for market-led development was short circuited by the rising "fear of communist expansion", and the need for more interventionist development, while the second coming of market driven development and the willingness of the leaders of the USA and elsewhere to accept whatever consequences the market may have- became politically feasible, in part, through the demise of communism.

We cannot, however, afford to deny that the intensity of global governance, power and control by the development organizations. But one can argue that it is because of the fluidity of the market. The nature of the present-day market system demands more control and surveillance as many argue. Interestingly, one of the shifts of the development organizations is remarkable: from 'good economics' to 'good government'. Despite concerns and criticisms, many think that this move is directed towards a positive outcome. For example, Cooper and Packard (1997) see:

The insistence on 'good government' reproduces much that was previously said about 'good economy': a bland assertion that the West has defined objective standards for others to meet, a generalized set of categories (elections, multiple parties) that define those standards, irrespective of the actual debates that might be going on in specific contexts over how more people might acquire meaningful voice in their own lives (p. 23).

Escobar (1995) claims that all development projects are economistic, as economics has the monopoly of authority in the area of development, which excludes other disciplines of social science. 'About $70 \%$ of the World Bank's professional staffs are economist; a good portion of the remaining 30\% are engineers' (p. 165). If this is true, this is alarming in deed. Recent years, however, witnessed a remarkable shift as researchers from different other disciplines (Sociology, Anthropology, Political Science, Environmental Studies...), not only as critics but also as contributors, ventured to penetrate into the border of development economics, and hence the new border of development area is blurring. The area of development is now interdisciplinary in nature. The point we want to make here is that thought the area of development is still dominated by Economics, the domination is subverted to a great extent. Lot of development activists, who are not economists, are working to create voice for the local people.

Both development and power are pervasive, yet complex, phenomena in our society. Complex character of both concepts as well as ideological orientations of scholars have led them view these concepts form different perspectives. Rather than rejecting one and accepting another, a comprehensive analysis of, and debate around, all perspectives has a good possibility to provide us a better understanding of the interwoven relations between these two most important concepts in our society. 


\section{References}

Bose, Sugata. (1997). "Instruments and Idioms of Colonial and national Development: India's Historical Experience in Comparative Perspectives" in Cooper, F. and R. Packard (ed.). International Development and Social Science: Essays on the History and Politics of Knowledge. Berkeley: University of California Press.

Brosius, J.P. A.L. Tsing, and C. Zerner. (1998). "Representing Communities: Histories and Politics of Community-Based Natural Resource Management" in Society and Natural Resources (2): 157-168

Brosius, Peter J. (1999). Green Dots, Pink Hearts: Displacing Politics from the Malaysian Rain Forest. In American Anthropologist 101 (1): 36-57

Brown, E. (1994). "Grounds at Stake in Ancestral Domains" in James Eder and Robert Yongblood eds. Patters of Power and Politics in the Philippines. Arizona: Arizona State University Press, pp 43-76.

Collins, Randall and Michael Makowsky. (1998). The Discovery of Society. New York: McGraw-Hill

Cooper, F. and R. Packard. (1997). "Introduction" in Cooper, F. and R. Packard (eds.) (1997). International Development and Social Science: Essays on the History and Politics of Knowledge. Berkeley: University of California Press.

Cooper, Frederick. (1997). Modernizing Bureaucrats, Backward Africans, and the Development Concept" in Frederick Cooper and Randall Packard (ed.). International Development and the Social Sciences: Essays on the History and Politics of Knowledge. Berkeley: University of California Press

Cowen, M.P. and R.W. Shenton. (1996). Doctrines of Development. London and New York: Routledge

Dahrendorf, Ralf. (1959). Class and Class Conflict in Industrial Society. Stanford, Calif.: Stanford University Press

Escobar, Arturo. (1992). 'Reflections on "Development": Grassroots Approaches and Alternative Politics in the Third World. Futures 24 (5): 411-36.

Escobar, Arturo. (1995). Encountering Development: the Making and Unmaking of the Third World. Princeton, NJ: Princeton University Press.

Fontana, Benedetto. (1993). Hegemony and Power: On the Relation between Gramsci and Machiavelli. Minneapolis: University of Minnesota Press

Foucault, M. (2000). 'Governmentality' in J. Faubian (ed.). Focault/Power. New York: New Press

Foucault, Michel. (1979). "On Governmentality", Ideology and Consciousness 6: 5-21; Foucault, "The Subject and Power", 208-26.

Foucault, Michel. (1986). The Use of Pleasure. New York: Pantheon Books.

Foucault, Michel. 1984. "Space, Knowledge, and Power". In Paul Rabinow (ed.). The Foucault Reader. New York: Pantheon Books. Pp. 239-256.

Foucault, Michel. (1991). "Governmentality", in Graham Burchell, Colin Gordon and Peter Miller eds.). The Foucault Effect. Studies in Governmentality. London: Harvester Wheatsheaf, Pp. 87-104.

Gitlin, Todd. (2003). The Whole World Is Watching: Mass Media In The Making \& Unmaking Of The New Left. Berkeley: University of California Press

Griffin, Keith. (1989). "Development in Historical Context" (Africa, Asia, and Latin America), Chapter 1 of Alternative Strategies of Economic Development. London: MacMillan/OECD Development Centre, 1989, pp. 1-23

Grinpun, Ricardo. (2003). "Exploring Links between Global Trade, Industrial Agriculture, and Rural Underdevelopment" in North, Liisa L. and J. D. Cameron (eds.) (2003). Rural Progress Rural Decay: Neoliberal Adjustment Policies and Local Initiatives. Connecticut: Kumarian Press, Inc.

Gupta, Akhil. (1997). "Agrarian Populism in the Development of Modern Nation (India)" in Frederick Cooper and Randall Packard (ed.). International Development and the Social Sciences: Essays on the History and Politics of Knowledge. Berkeley: University of California Press

Hall, Stuart. (1991). "Old and New Identities". Old and New Ethnicities in King. A.D. (ed.) Culture, Globalization and the World System: Contemporary Conditions for the Representation of Identity. Basingstoke: McMillan

Hall, Stuart. (1996). “Introduction: Who Needs Identity?” in Questions of Cultural Identity. Stuart Hall and Paul du Gay (eds.). London: Sage

Hameed, A. Khan. (1997). "The Orangi Pilot Project: Uplifting Periurban Settlement near Karachi” in Anirudh Krishna et al (eds.). Reasons for Hope: Instructive Experiences in Rural Development. West Hartford: Kumarian Press 
Hoogvelt, Ankie. (2001). Globalization and the Postcolonial World: New Political Economy of Development. Baltimore, Maryland: The Johns Hopkins University Press

Hunt, Diana. (1989). Economic Theories of Development: An Analysis of Competing Paradigms. New York: Harvester Wheatsheaf

Islam, Md. Saidul. (2003) "Labelling Tribals: Forming and Transforming Bureaucratic Identity in Thailand and Indonesia in a Historical Setting" in Gateway, Vol. 3, No. 1, pp. 1-13

Keck, Margaret E. and Kathryn Sikkink. (1998). Activists beyond Borders: Advocacy Networks in International Politics. Ithaca, N.Y. : Cornell University Press

Khor, Martin. (2001). Rethinking Globalization: Critical Issues and Policy Choices. London; New York: Zed Books

Lefeber, Louis (2003). "Problems of Contemporary Development: Neo-liberalism and its Consequences" in North, Liisa L. and J. D. Cameron (eds.). (2003). Rural Progress Rural Decay: Neoliberal Adjustment Policies and Local Initiatives. Connecticut: Kumarian Press, Inc.

Leys, Colin. (1996). The Rise and Fall of Development Theory. Indiana: Indiana University Press

Li, Tania. (2000). "Constituting Tribal Space: Indigenous Identity and Resource Politics in Indonesia" Comparative Studies in Society and History. January

Li, Tania. (2002). Engaging Simplifications: Community-Based Resource Management, Market Processes and State Agendas in Upland Southeast Asia" in World Development 30(2): 265-83

Lohmann, Larry. (1999). Forest Cleansing: Racial Oppression in Scientific Nature Conservation. The Corner House. Briefing No. 13: Forest Cleansing.

Luke, Timothy W. (1999). Environmentality as Green Governmentality. Discourses of the Environment. Eric Darier (eds.) Blackwell.

Lukes, Steven (ed.). (1986). Power. New York: New York University Press

Lynch, O. and K. Talbot. (1995). Balancing Acts: Community Based Forest Management and National Law in Asia and the Pacific. Washington, DC: World Resource Institute.

Marx, Karl. (1998). The Communist Manifesto. New York: Verso

Marx, Karl, Frederick Engels, Valdimir Lenin. (1975). Dialectical And Historical Materialism. Moscow: Progress Publishers

McMichael, Philip. (2000). Development and Social Change. London: Pine Forge Press

Murray, G. F. (1997). “A Haitian Peasants Tree Chronicle: Adaptive Evolution and Institutional Intrusion” in Anirudh Krishna et al (eds.). Reasons for Hope: Instructive Experiences in Rural Development. West Hartford: Kumarian Press

Packard, Randall. (1997). "Visions of Post-War Health and Development and Their Impact on Public Health Intervention in the Developing World" in Frederick Cooper and Randall Packard (ed.). International Development and the Social Sciences: Essays on the History and Politics of Knowledge. Berkeley: University of California Press

Panitch, Leo (ed.). (1977). The Canadian State: Political Economy and Political Power. Toronto: University of Toronto Press

Pett, Richard, and Elaine Hartwick. (1999). Theories of Development. New York: Guilford Press

Rist, Gilbert. (2002). The History of Development: From Western Origin to Global Faith. NY: Zed Books Ltd

Rostow, Walt W. (1960). The Stages of Economic Growth: A Non-Communist Manifesto. Cambridge: Cambridge University Press

Sachs, W. (1992). "Development: A Guide to the Ruins". The New Internationalists. June.

Schroeder, R. (1995). Contradictions along the Commodity Road to Environmental Stabilization: Foresting Gambian Gardens. Antipode 25(4): 325-342.

Scott, James C. (1998). Seeing Like a State: How Certain Schemes to Improve Human Condition Have Failed. London: Yale University Press.

Stiglitz, Joseph. (2000). "What I learnt from the world economic crisis" in New Republic Online

Strange, Susan. (1996). The Retreat of the State: The Diffusion of Power in the World Economy. New York: Cambridge University Press.

UNDP Human Development Report. (1993). 
Vandergeest, Peter. (2003). "Land to some tillers: Development-induced displacement in Laos", International Social Science Journal LV (1): 47-56.

Vandergeest, P. and N. Peluso. (1995). Territorialization and State Power in Thailand. Theory Soc. 24(3) 385:426

Weisbrot, Mark et al. (2000). "Growth May be Good for the Poor- but are IMF and World Bank Policies Good for Growth? A Close Look at the World Bank's Most Recent Defense of Its Policies. Centre for Economic and Policy Research. Briefing Paper.

Wood, Geof. (1997). "States without Citizen: The problem of Franchise State" in David Hulme and Michael Edwards (eds.). NGOs, States and Donors: Too Close for Comfort? New York: St. Martins Press

\section{Notes}

Note 1. For example, Wolfgang Sachs (1992) writes: "The idea of development was once a towering monument inspiring international enthusiasm. Today, the structure is falling apart and in danger of total collapse" (p. 5).

Note 2. It has become commonplace to note that the 'Third World' and 'Second World' have ended as coherent entities. Secondly, many might think that using 'Third World' exposes its subordinate power relation with the so-called 'First World'. We use Third World here for no other reason than convenience.

Note 3. Gramsci is an Italian political activist and theorist who wrote much of his most influential work while incarcerated in a fascist prison, Gramsci has left an enduring legacy. His notion of hegemony is quite similar to Althusser's participatory model, where even the oppressed classes happily accede to their oppression. However, Althusser's differs insofar as he thinks social change is rendered unlikely. Gramsci's theory, on the other hand, allows a much greater role for resistance to dominating influences/power from within the hegemonized groups, and recognizes the opportunity for social change within a capitalist system. 